\title{
Impact of Emotional Intelligence on Turnover Intentions: The Role of Organizational Commitment and Perceive Organizational Support
}

\author{
Muhammad Waheed Akhtar ${ }^{1 *}$, Atif Shabir ${ }^{1}$, Muhammad Shahid Safdar ${ }^{1}$ and Muhammad Saeed Akhtar ${ }^{2}$
}

${ }^{1}$ Faculty of Management Sciences, International Islamic University, Islamabad, Pakistan

${ }^{2}$ Department of Business Administration, National College of Business Administration and Economics, Bahawalpur, Pakistan

\begin{abstract}
The purpose of this research is to investigate the moderating role of Perceived Organizational Support in the relationship between Emotional Intelligence and organizational commitment, investigate the mediating role of organizational commitment in the relationship between Emotional Intelligence and turnover intentions. Data were gathered through self-administered questionnaire from a sample of 348 employees working in telecom industry located in Lahore. The data were analysed statistically using IBM SPSS Statistics 22 to find out correlation and regression analysis between study variables, reliability of research instrument, strength of relationship between independent and dependent variables, mediating effect of organizational commitment in the relationship between Emotional Intelligence and turnover intentions, moderating effect Perceived Organizational Support in the relationship between Emotional Intelligence and organizational commitment was also substantiated. Findings suggest that Emotional Intelligence have a positive impact on organizational commitment, Emotional Intelligence have a negative impact on turnover intentions, and organizational commitment mediate the relationship between Emotional Intelligence and turnover intentions, and Perceived Organizational Support moderate the relation between Emotional Intelligence and organizational commitment.
\end{abstract}

Keywords: Emotional Intelligence (EI); Perceived Organizational Support (POS); Organizational commitment; Turnover intentions

\section{Introduction}

Emotional Intelligence (EI) is a psychological factor which can increase employee's ability and performance. Highly Emotional Intelligence employees are able to produce good quality products and services at their work environment. At the same time by enhancing employees' Emotional Intelligence level their task performance will increase. Many researchers argued that EI played significant role at work environment [1-4]. From the recent discussion of management new idea came, which is EI and it is effect on organizational member's performance. Cote and Miners [5] argued that high EI level of employees' leads to high performance. In recent years Emotional Intelligence is a topic of interest [6]. Goleman [7] stated that Emotional Intelligence effects on employees success with in organization. Emotional Intelligence increased employee's productivity and performance [8].

Under this rationale, several empirical studies have provided supporting evidence that turnover, job satisfaction, intentions to quit and job performance are the results of employees EI $[9,10]$. Many researches supported that organizational commitment, job satisfaction and leadership support are the factors effecting on turnover and intentions to quit $[11,12]$. In addition, many researchers provided evidence of a negative relation between EI and turnover intention [1316]. Such managerial issues have been approached in numerous studies with the employment of computational methods $[17,18]$.

Many researchers investigate the effect of EI on organizational commitment [19-21], EI and turnover intentions intention [1315]. But still there is a gap which needs to be investigation. Such as organizational commitment mediating role in the relationship between Emotional Intelligence and turnover intentions. Mostly employees perceive employment as reciprocal exchange relationship which reproduces formal contract and relative dependence [22]. And in organizational research this type of employee's perception is very important because organization and employees, both are involved in reciprocal relationship. Chen at al. [23] argued that it is not enough to investigate single side relationship but we must examine organizational support gives to its employees. When employees are highly EI and organization giving them fair and equal organization support against their contribution then the employee's commitment level and performance level increased. And that's why the present study going to fulfil this gap and going to investigates the moderating role of POS in the relationship between Emotional Intelligence and organizational commitment.

\section{Problem statement}

Telecom sector is gradually becoming competitive in small medium enterprises around the world. Therefore, at the augmented product level telecom firms need to differentiate themselves from competitors. For that reasons telecom firms focusing on their employees as a competitive advantage because it is difficult to imitate. However, in telecom firm's modern practices replaced the traditional one but nature of work unchanged and problems are still there. In banks we commonly observe the unsatisfied employees, they just doing the job to support their families and to deal with their financial problems. It's an empirical observation, dissatisfaction at work destroying the employee's ability at work, i.e., fatigue, depression, lack of will to develop the tasks, producing them in a bad mood and sleeping disorders. And the dissatisfaction at work leads toward low organizational commitment

*Corresponding author: Muhammad Waheed Akhtar, PhD. Scholar, Faculty of Management Sciences International Islamic University, Islamabad, Pakistan, Tel: +92519257988; E-mail: waheedakhtarms@gmail.com

Received November 10, 2017; Accepted November 28, 2017; Published December 12, 2017

Citation: Akhtar MW, Shabir A, Safdar MS, Akhtar MS (2017) Impact of Emotiona Intelligence on Turnover Intentions: The Role of Organizational Commitment and Perceive Organizational Support. J Account Mark 6: 259. doi: 10.4172/21689601.1000259

Copyright: @ 2017 Akhtar MW, et al. This is an open-access article distributed under the terms of the Creative Commons Attribution License, which permits unrestricted use, distribution, and reproduction in any medium, provided the original author and source are credited. 
and high employees turnover intentions. That's why present study focuses on this issue.

\section{Research questions}

Following are the research questions

1. Dose Perceived Organizational Support (POS) moderates the relationship between Emotional Intelligence (EI) and organizational commitment?

2. Does organizational commitment mediate the relationship between EI and employees turnover intentions?

\section{Significance of study}

The aims of present study are examined the mediating role of organizational commitment in the relationship between Emotional Intelligence and turnover intentions, and furthermore investigate the moderating role of POS in the relationship between EI and organizational commitment. And therefor present study added the value in the literature EI, organizational commitment and turnover intentions. Moreover it added in the literature of POS as a moderator between Emotional Intelligence and organizational commitment and organizational commitment as mediator between EI and turnover intentions. According to the best knowledge this the first study in Pakistan which explore the mediating role organizational commitment between Emotional Intelligence and turnover intentions and also explore the moderating role of POS between Emotional Intelligence and organizational commitment. Present study has many managerial implications; firstly creates awareness in managers related to EI and employees EI effects on their organizational commitment and turnover intentions in the case of telecom industry. Second, present study provide the helping hand to manager for understanding the role of POS and how POS effects on employees commitment level in telecom industry.

\section{Literature Review}

\section{Emotional intelligence}

New field of research in the area business and management is Emotional Intelligence. In 1990 theory of Emotional Intelligence was presented by Salovey and Mayer [24]. They defined the Emotional Intelligence as "the ability to perceive accurately, appraise, and express emotions; the ability to access and/or generate feelings when they facilitate thought; the ability to understand emotions and emotional knowledge; and the ability to regulate emotions to promote emotional and intellectual growth". In 1997 the ability model of Emotional Intelligence was presented by Mayer and Salovey [25]. Ability model of EI consists of four components; first self-emotion appraisal, second others emotions appraisal, third regulation of emotions and fourth is use of emotions $[1,4]$

Zeidner et al. [26] argued that there are two models of EI; first ability model of EI and Second, mixed model of EI. In ability model of EI, focused on ability for handling information regarding emotions. Ability model is a set of cognitive or mental abilities used for the processing of emotional information and regulations of emotions. Second, Goleman [27] and Bar-On [28] explored the mixed model of EI. Mixed models of EI focused on emotional abilities in personality factors and traits context and due to this these models are referred as mixed models [29,30]. At mixed models of EI many critics raise their concerns on the construct of EI validity. Present study focused on ability model because no researcher criticizes on its validity.

\section{Turnover intentions}

Employees turnover define as "number of organizational employees quit within a specific time period, normally one year in relations to the total number of employees" [31]. Sellgren et al. [31] stated that employee's intentions to quit are associated with high cost such as new employee's recruitment and it is also have negative effects on services quality. Wong and Law [1] suggested that employees high in EI will be less likely to leave their jobs, while employees low in EI will be more likely to do so. Other justifications for expecting a negative correlation between EI and turnover intentions are derived from the levels of organizational commitment and leader-member exchange among high and low EI employees. Given that high EI individuals are more committed to their organizations, it is reasonable to assume that such employees will be less likely to leave. Low EI employees, however, are more likely to leave their organizations given that: they are less committed to their organizations [13].

Past research has confirmed a negative association between turnover intentions and EI [13-15], [32-34]. Wong and Law [1] stated that higher the emotional labour inn a particular job and significantly negative relations between Emotional Intelligence and turnover intentions. On the basis of this we proposed that:

H1: Emotional Intelligence has negative impact on employee's turnover intentions.

\section{Organizational commitment}

Porter et al. [35] define the organizational commitment as "the strength of an individual's identification with an involvement in a particular organisation". Organizational commitment is the employee's degree of loyalty and attachment towards the organization. Employees with higher Emotional Intelligence are more committed to their organizations [21], higher level of performance [27], attain higher success. George [3] argued that high EI employees are good in interpersonal relationship and enjoy cooperation and trust. Dulewics and Higgs [36] revealed that employees with higher level of EI are achieving more career success as compare to low EI employees. Cooper and Sawaf [37] said that employees with higher level of EI are effectively leads the people as compare to low EI employees. Jordan et al. [20] revealed that employees with higher level of EI are feeling less job insecurity as compare to low EI employees.

Many researchers argued that there is a significant and positive relationship between Emotional Intelligence and organizational commitment $[19,38]$. Researcher also stated that EI is a key factor in increasing employee's organizational commitment [21]. There is positive and significant relationship between Emotional Intelligence and organizational commitment [13]. On the basis of above arguments we propose that:

$\mathrm{H} 2$ : Emotional Intelligence has a positive impact on organizational commitment.

Many researchers revealed that lack of commitment have harmful effects such as turnover intentions, high rate of turnover, tardiness, higher absenteeism level and poor performance [39-41] argued that satisfied employees are more committed as compare to dissatisfied employees have high level of absenteeism and turnover. Mowday and Spencer [42] argued that organizational commitment positively related to performance and negatively related to absenteeism and turnover. McNeilly and Russ [43] found that commitment was negatively related to turnover intentions. On the basis of above arguments we proposed that: 
H3: Organizational commitment has a negative impact on turnover Intentions.

Based on the previous literature we can say that organizational commitment mediates the relationship between Emotional Intelligence and turnover intentions. Because employees with high EI are more committed with their job and organization, and that's why these employees have less turnover intentions. And the basis of above argument we hypothesised that:

H4: Organizational commitment mediates the relationship between Emotional Intelligence and turnover intentions.

\section{Perceived Organizational Support (POS)}

For long term survival and development in competitive environment organizations need to keep dedicated employees. Many researchers investigate the factors that effects on employee's dedication and attachment [44-46]. Einsenberger et al. [47] describe the POS as "the extent to which the organization values their employees' contributions and cares about their well-being". Malatesta and Tetrick [48] argued that supportive organizations are committed to their employees.

Blau [49] investigate the relationship between Perceived Organizational Support and organization commitment. Rhoades and Eisenberger [50] stated that POS is employee's belief that organization rewards their employees for the effort made on its behalf. Gouldner [51] stated that POS encourage employees to reciprocate to their part. Researchers argued that POS increased employee's commitment and engagement level which is beneficial for organization.

Perceived Organizational Support (POS) create a felt obligation to care about the organization [22]. Fao and Fao [52] argued that caring for caring should increase the employee's commitment level. Many researchers argued that POS increase employees commitment by fulfilling emotional needs such as affiliation and emotional support $[47,53]$. Fulfilment of employees emotional needs produce a strong sense of belonging with organization. Akhtar et al. [54] investigated the moderating role of POS.

By studying the existing literature we stated that there is significant positive relationship between Perceived Organizational Support and organizational commitment, but yet we need to examine the moderating role of POS between EI and organizational commitment. Accordingly, POS moderate the relationship between EI and organizational commitment, because employees with high Emotional Intelligence have higher commitment level but if the highly emotional intelligent employees perceived low organizational support than their commitment level decreased, but if the highly emotional intelligent employees perceived high organizational support than their commitment level enhance. On the basis of above arguments we proposed:

H5. POS moderates the relationship between EI and organizational commitment, such that the relationship between EI and organizational commitment is stronger/positive when POS is high.

\section{Conceptual framework}

Model for the present study is defined in Figure 1.

\section{Methodology}

\section{Sample size}

This is quantitative study. Data were gathered from the employees

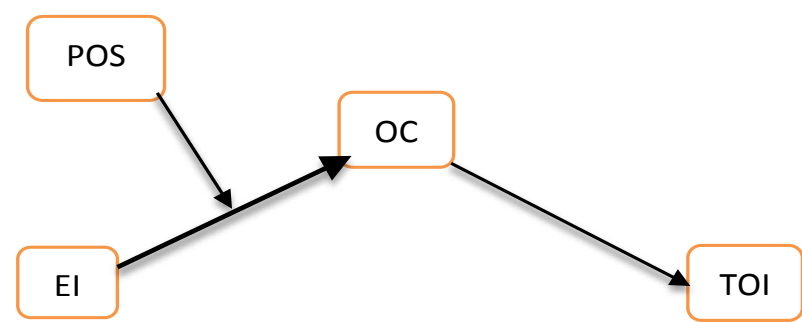

Figure 1: Conceptual framework.

by using the questionnaire survey techniques. Targeted population of the present study was telecom industry, and employees are the unit of analysis. Data were gathered once from employees in telecom sector. The respondents of this study are the employees of the city of Lahore. For the collection of data we used convenience sampling technique. The survey was conducted in the month of February, 2015.

To identify the sufficient sample size we used the Rule-of-10 technique. By which for each question item we take response of 10 participants [55,56]. In present study, we have 39 items of questionnaire; by which Emotional Intelligence have 16, POS have 8 items, organizational commitments have 9 items and turnover intentions have 6 items. The reasonable sample size of present study is $390(39 \times 10)$.

\section{Measurements}

All variables of the study measured through standard instruments developed and validated previously. We measured Emotional Intelligence by using WLIES scale developed by Wong and Law [1]. The sample question is "I have good understanding of my own emotions?" For the measurement of Perceived Organizational Support we used the shot version of Eisenberger et al. [47]. This short version consists on 8 items. The sample of question is "The organization values my contribution to its well-being?" For the measurement of organizational commitment we used the nine item questionnaire [57]. The sample question is "Willing to put forth great effort to help organization succeed"? For the measurement of turnover intentions we used 6 items scale. We used four items from [58] scale and additionally two items are used from the scale of Lucas [59]. The sample question is "How often you contemplate quitting your job"? All respondents gave their response on five point Likert scale, and the scale range is strongly disagree [1] to strongly agree [5].

\section{Data collection}

All the respondents of present study are the employees who are working in different branches of telecom industry at Lahore. All the respondents were approached either by researcher or through research facilitator. Research facilitator are researcher friends and working at different telecom firms. They were asked to collect data from their respective organizations only.

Respondents firstly read and understand the statement and then give their response about how they feel, think or act in their organizations by encircling the most appropriate number in given scale. Respondents were assured of confidentiality of responses as all data were collected anonymously (respondent's name was not taken). All the participants were also allowed to take time in completing the questionnaire. 400 questionnaires were distributed among the employees working in different telecom firms at Lahore. Out of which 365 questionnaires were returned, providing the response rate $91 \%$. 
Citation: Akhtar MW, Shabir A, Safdar MS, Akhtar MS (2017) Impact of Emotional Intelligence on Turnover Intentions: The Role of Organizational Commitment and Perceive Organizational Support. J Account Mark 6: 259. doi: 10.4172/2168-9601.1000259

Page 4 of 7

\section{Control variable}

For the identification of control variables we perform one way ANOVA test (Table 1). And in the result of that test we said that qualification have a significant effect on turnover intentions, that's why qualification should be treated as control variable in present study.

\section{Data Analysis and Discussion}

\section{Demographic results}

Table 2 shows the result of respondents demographic; by which include age, gender and education. Most of the respondents are below than 36 years $(76 \%), 68 \%$ of respondents are male and $51 \%$ respondents are having the degree of master.

\section{Descriptive statistics and inter-correlations among construct}

In descriptive statistics include the detail of mean, standard deviation of all variables of study (Table 3 ). In descriptive statistics include mean, standard deviation, correlation and reliabilities. The means of EI is (3.71), POS (3.50), organizational commitment (3.72) and turnover intentions (1.78). The values of standard deviations of EI are (0.71), POS (0.74), organizational commitment (0.73) and turnover intentions (0.78). The values of Cronbach's alpha of Emotional Intelligence is $(0.93)$, POS (0.84), organizational commitment $(0.88)$ and turnover intentions (0.917).

Emotional Intelligence is positively correlated with POS and organizational commitment, there values are 0.651 and 0.677 , respectively. POS positively correlated with organizational commitment (0.666). And turnover intentions are negatively correlated with Emotional Intelligence, POS and organizational commitment, and there values are $-0.727,-0.643$ and -0.775 , respectively.

\begin{tabular}{|l|c|c|c|c|c|}
\hline & Sum of Squares & Df & Mean Square & F-value & Significance \\
\hline Between groups & 72.703 & 30 & 2.423 & 8.532 & .000 \\
\hline Within groups & 90.323 & 318 & .284 & & \\
\hline Total & 163.026 & 348 & & & \\
\hline
\end{tabular}

Df: Degree of freedom.

Table 1: ANOVA test.

\begin{tabular}{|l|l|l|}
\hline \multicolumn{2}{|l|}{ Demographics } & \multicolumn{1}{l|}{ Per cent } \\
\hline Age & $18-25$ & 35.8 \\
\hline & $26-35$ & 39.8 \\
\hline \multirow{5}{*}{ Gender } & $36-45$ & 22.1 \\
\hline & 46 Or above & 2.3 \\
\hline Education & Male & 68 \\
\hline & Female & 32 \\
\hline & Graduation & 33 \\
\hline & Master & 51 \\
\cline { 2 - 3 } & MS/PhD & 16 \\
\hline
\end{tabular}

Table 2: Demographic results.

\begin{tabular}{|l|l|l|l|l|l|l|}
\hline & Mean & SD & EI & POS & OC & TOI \\
\hline EI & 3.71 & 0.71 & $(0.93)$ & & & \\
\hline POS & 3.50 & 0.74 & $0.651^{* *}$ & $(0.82)$ & & \\
\hline OC & 3.72 & 0.73 & $0.677^{\star *}$ & $0.666^{* *}$ & $(0.88)$ & \\
\hline TOI & 1.78 & 0.78 & $-0.727^{* *}$ & $-0.643^{* *}$ & $-0.775^{* *}$ & $(0.917)$ \\
\hline
\end{tabular}

El: Emotional Intelligence; POS: Perceived Organizational Support; OC: Organizational Commitment; TOI: Turnover Intentions.

${ }^{\star *}$ Correlation is significant at the level of 0.01 (2- tailed). Table 3: Correlation among the variables of the study.

\section{Regression analysis}

For the regression analysis we carried out several hierarchical regressions to test EI, POS, organizational commitment and turnover intentions.

Hypothesis 1 stated that EI has a negative impact on turnover intentions. Table 4 shows the results of regression analysis and indicates that Emotional Intelligence has a significant negative impact on turnover intentions $(\beta=-0.727, p=0.000)$ and the value of $R^{2}$ is 0.53 . Hypothesis 1 is accepted because results are significant and negative in direction. These results are according to the findings [1,13,15,27,32-34].

Hypothesis 2 stated that EI has a positive impact on organizational commitment. Table 5 shows the results of regression and indicates that Emotional Intelligence has a significant positive impact on organizational commitment $(\beta=0.677, p=0.000)$ and the value of $\mathrm{R}^{2}$ is 0.458 . Hypothesis 2 is accepted because results are significant and positive in direction. These results are according to the findings $[13,19,38]$.

Mediation regression analysis: We used Mediation Regression Analysis to test hypothesis 4, proposed by Baron and Kenny [60]. According to them three conditions must be fulfil for mediation relationship: First, all independent variables proved as the significant predictors of dependent variable. Secondly, all independent variables proved as the significant predictors of mediator. Thirdly, the mediating variable must be proved as significant predictor of dependent variable.

For the mediational regression, dependent variable is regressed on independent and mediator variable. If all the conditions are satisfied mediation occurred. When we entered mediator in the equation and independent variable become non-significant than full mediation is ascertained. And if the effect of independent variable is decreased after entering the mediating variable in equation then partial mediation occurred.

Hypothesis 3 stated that organizational commitment has a negative impact on turnover intentions. Table 6 shows the results of regression and indicates that organizational commitment has a significant negative impact on turnover intentions $(\beta=-0.523, p=0.000)$. Hypothesis 3 is accepted because results are significant and negative in direction. These results are according to the findings $[39,40]$.

Hypothesis 4 proposed that organizational commitment mediate the relationship between EI and turnover intentions. In order investigate the mediation effect we regressed turnover intentions on Emotional Intelligence (EI) and organizational commitment together. The results of mediation regression are shown in Table 6. The effect of (EI) Emotional Intelligence decreased after entering the

\begin{tabular}{|l|l|l|l|l|}
\hline Predictor & $\boldsymbol{\beta}$ & $\mathbf{R}^{\mathbf{2}}$ & $\Delta \mathbf{R}^{\mathbf{2}}$ & Sig. \\
\hline Step 1: Control & -0.12 & 0.015 & & 0.024 \\
\hline Step 2: El & -0.73 & 0.53 & 0.527 & 0.000 \\
\hline
\end{tabular}

Dependent variable: TOI; $\mathrm{N}=348$; Control variable: Qualifications.

Table 4: Effect of El on turnover intentions.

\begin{tabular}{|l|l|l|l|l|}
\hline Predictor & $\boldsymbol{\beta}$ & $\mathbf{R}^{\mathbf{2}}$ & $\Delta \mathbf{R}^{\mathbf{2}}$ & Sig. \\
\hline Step 1: Control & 0.10 & 0.011 & & 0.04 \\
\hline Step 2: El & 0.688 & 0.46 & 0.457 & 0.000 \\
\hline
\end{tabular}

Dependent variable: $\mathrm{OC}, \mathrm{N}=348$.

Table 5: Effect of EI on OC. 


\begin{tabular}{|l|l|l|l|l|}
\hline Predictor & $\boldsymbol{\beta}$ & $\mathbf{R}^{\mathbf{2}}$ & $\Delta \mathbf{R}^{\mathbf{2}}$ & Sig. \\
\hline Step 1: Control & -0.12 & 0.015 & & 0.024 \\
\hline Step 2: El & -0.727 & 0.53 & 0.515 & 0.000 \\
\hline Step 3: El & -0.373 & 0.67 & & 0.000 \\
\hline Step 3: OC & -0.523 & & 0.147 & 0.000 \\
\hline
\end{tabular}

Dependent variable: TOI; N=348; Control variable: Qualifications.

Table 6: The mediating role of organizational commitment in the relationship between Emotional Intelligence and turnover intentions.

\begin{tabular}{|l|l|l|l|l|}
\hline Predictor & $\boldsymbol{\beta}$ & $\mathbf{R}^{2}$ & $\Delta \mathbf{R}^{2}$ & Sig. \\
\hline Step 1: Control & 0.106 & 0.011 & & 0.047 \\
\hline Step 2: El & 0.429 & 0.547 & 0.535 & 0.000 \\
\hline Step 2: POS & 0.388 & & & 0.000 \\
\hline Step 3: El & 0.64 & 0.554 & 0.008 & 0.000 \\
\hline Step 3: POS & 0.686 & & & 0.000 \\
\hline Step 3: EPOS & -0.47 & & & 0.016 \\
\hline
\end{tabular}

Dependent variable: OC; $N=348$; Control variable: Qualifications.

Table 7: The moderating role of perceived organizational support in the relationship between Emotional Intelligence and organizational commitment.

organizational commitment $(\beta=-0.727, p=0.000$ to $\beta=-0.373, p=0.000)$. Since the results are significant and in the predicted direction, therefore hypothesis 4 is accepted.

\section{Moderation regression analysis}

For testing hypothesis 5 we used moderation regression analysis. Perceived Organizational Support as a moderator in the relationship between Emotional Intelligence and organizational commitment. Hypothesis 5 stated that Perceived Organizational Support moderates the relationship between Emotional Intelligence and organizational commitment, such that the relationship between Emotional Intelligence and organizational commitment is stronger/positive when POS is high.

To test $\mathrm{H} 5$ we centred round all variables on their means. In step 2 we entered EI entered, in step 3 we entered EI and POS together and in step 4 we entered interaction term EPOS (EI*POS) keeping organizational commitment as dependent variable.

Results in Table 7 revealed that EI and POS are significant predictor of organizational commitment $(\beta=0.429, p=0.000$ to $\beta=0.388$, $\mathrm{p}=0.000$ ), respectively. Value of $\beta$ shows that higher level of POS, the organizational commitment will be even higher as a result. By adding the interaction term we found $\left(\Delta \mathrm{R}^{2}=0.008, \mathrm{p}=0.016<0.05\right)$ both the change in $\mathrm{R}$ square and $\mathrm{p}$ value are less than 0.05 and significant. In interaction plot also shows that POS moderates the relationship between EI and organizational commitment. So hypothesis 5 (H5) accepted.

\section{Conclusion}

In current study we investigates the effect of Emotional Intelligence on turnover intentions, effect of Emotional Intelligence on organizational commitment, effect of organizational commitment on turnover intentions, mediating role of organizational commitment in the relationship between Emotional Intelligence and turnover intentions, and also investigates the effect of POS as moderating variable in the relationship between Emotional Intelligence and organizational commitment. In general the findings of present study are consistent with the hypothesis set. The result of present study revealed that Emotional Intelligence have a negative impact on employee's turnover intentions. Findings of present study revealed that Emotional

Intelligence have a positive impact on organizational commitment. Findings of present study revealed that organizational commitment have a significant negative impact on turnover intentions. And that's why organizational commitment mediates the relationship between EI and turnover intentions. Because high EI employees are more committed with their organizational and have less turnover intentions.

Perceived Organizational Support moderates the relationship between Emotional Intelligence and organizational commitment. Because employees with high EI perceive low organizational support then their level of commitment toward organization also decreased. And when highly EI employees perceive high organizational support then their level of commitment towards organization is high. And that's why POS moderates the relationship between Emotional Intelligence and organizational commitment. And based on the finding researcher give the suggestion that organization provide training related to Emotional Intelligence to their manager so that they can identify, regulate and use their own emotions and the emotions of others employees.

\section{Limitations of the Study}

Present study have cross sectional data for analysis; we found more variance if our collected data will longitudinal in nature. As there is always room for improvement. Present study investigated the effect of EI on organizational commitment and turnover intentions: moderating role of POS in the relationship between EI and organizational commitment, used convenience sampling method, limited sample size, and conducted at Lahore telecom firms. Thus needs a more comprehensive study, to be examined with increasing sample size. More industries should have studies and make a comparison among different sectors Emotional Intelligence impact on organizational commitment and turnover intentions: moderating role of POS between EI and organizational commitment relationship.

\section{Managerial Implications of Study}

Surveying the reasons for 3149 employees who voluntarily left their organizations, Branham [61] found that very few of the reasons for exiting were based on thinking; mostly they originated out of strong feelings/emotions like disappointment, frustration, anger and resentment. The cost to the company of a leaving employee was calculated to be at least the cost of his/her annual salary [62]. Farooq [62] suggested facilitating the selection process by identifying the soft skills required for a particular job. Fatt [63] argued that managers should measure applicants' EI to evaluate their competencies before hiring them. And based on the finding researcher give the suggestion that organization provide training related to Emotional Intelligence to their manager so that they can identify, regulate and use their own emotions and the emotions of other employees. The practical implications of present study is not just limited to improving Emotional Intelligence of employees but also focused on organizational support for employees so that employees performance will reached at maximum level. This strategy will work as a proactive measure to reduce turnover. Furthermore, employees with high EI will be fine-tuned to the needs, responses, attitudes and behavior of colleagues, customers, public and media; thus, improving their performance qualitatively.

Many researchers stated that emotional competencies can be increased and developed through training courses [64-66]. Fatt [63] recommended that managers should consider the contributions of EI as an important factor for the development of staff. The current study indicated a high and positive association of EI with employee performance. Hence, organizations can design EI interventions to train and develop human resources to get work performance improved. 
Citation: Akhtar MW, Shabir A, Safdar MS, Akhtar MS (2017) Impact of Emotional Intelligence on Turnover Intentions: The Role of Organizational Commitment and Perceive Organizational Support. J Account Mark 6: 259. doi: 10.4172/2168-9601.1000259

Page 6 of 7

\section{Future Directions}

The findings of present study reveals that there is negative relationship between EI and turnover intentions, positive relationship between EI and organizational commitment, organizational commitment mediate the relationship between EI and turnover intentions, and also POS moderate the relationship between Emotional Intelligence and organizational commitment, such that the relationship between Emotional Intelligence and organizational commitment more stronger/positive when POS is high. However, there can be other possible factors which can be studied and investigate as future research such as organizational politics.

We used quantitative approach, by using questionnaire survey from telecom sector at Lahore. Thus for future direction it is recommended that data will collected by using qualitative approach (interview). Data were gathered from Lahore, so that's why similar research design will implement in other cities in different sectors as a future research. Present study investigated the mediating role of organizational commitment between Emotional Intelligence and turnover intentions, and also investigated the moderating effect of Perceived Organizational Support between Emotional Intelligence and organizational commitment. But still there is a gap which needs to be investigation such EI, job performance, task performance, organizational political; moderating role of POS in the relationship between EI and task performance. The researcher hopes this study will make a good contribution in the existing literature and knowledge and provide some useful recommendations for Pakistan telecom sector.

\section{References}

1. Wong CS, Law KS (2002) The effects of leader and follower emotional intelligence on performance and attitude: an exploratory study. The Leadership Quarterly 13: 243-274.

2. Sy T, Tram S, O'Hara LA (2006) Relation of employee and manager emotional intelligence to job satisfaction and performance. Journal of Vocational Behavior 68: $461-473$

3. George JM (2000) Emotions and leadership: The role of human intelligence. Human Relations 53: 1027-1055.

4. Law KS, Wong CS, Song LJ (2004) The construct and criterion validity of emotional intelligence and its potential utility for management studies. Journal of Applied Psychology 89: 483-496.

5. Cote S, Miners CT (2006) Emotional intelligence, cognitive intelligence, and job performance. Administrative Science Quarterly 51: 1-28.

6. Mayer JD, Salovey P, Caruso DR, Sitarenios G (2003) Measuring emotional intelligence with the MSCEIT V2. 0. Emotion 3: 97.

7. Goleman D (2001) An El-based theory of performance.The Emotionally Intelligent Workplace, Jossey-Bass, San Francisco, CA.

8. Lam LT, Kirby SL (2002)Is emotional intelligence an advantage? An exploration of the impact of emotional and general intelligence on individual performance. The Journal of Social Psychology 142: 133-143.

9. Sy T, Tram S, O'Hara LA (2006) Relation of employee and manager emotional intelligence to job satisfaction and performance. Journal of Vocational Behavior 68: $461-473$

10. Trivellas $P$, Gerogiannis V, Svarna S (2011) The impact of Emotional Intelligence on job outcomes and turnover intention in Health Care. ICININFO-2011, Advances on Information Processing and Management (AIPM) 1: 356-360.

11. Price JL (2001) Reflections on the determinants of voluntary turnover International Journal of Manpower 22: 600-624.

12. Chiu CK, Chien CS, Lin CP, Yun Hsiao C (2005)Understanding hospital employee job stress and turnover intentions in a practical setting: The moderating role of locus of control. Journal of Management Development 24: 837-855

13. Carmeli A (2003) The Relationship between Emotional Intelligence and Work
Attitudes, Behaviour, and Outcomes: An Examination among Senior Managers. Journal of Managerial Psychology 18: 788-813.

14. Goleman D (1999) Working with emotional intelligence, London: Bloomsbury Publishing.

15. Kooker BM, Shoultz J, Codier EE (2007) Identifying emotional intelligence in professional nursing practice. Journal of Professional Nursing 23: 30-36.

16. Vakola M, Tsaousis I, Nikolaou I (2004) The role of emotional intelligence and personality variables on attitudes toward organisational change. Journal O Managerial Psychology 19: 88-110.

17. Larson EB, Yao X (2005) Clinical empathy as emotional labor in the patientphysician relationship. JAMA 293: 1100-1106.

18. Vlachos DS, Simos TE (2004) Partitioned Linear Multistep Method for Long Term Integration of the N-Body Problem. Applied Numerical Analysis and Computational Mathematics 1: 540-546.

19. Abraham R (2000) The role of job control as a moderator of emotional dissonance and emotional intelligence-outcome relationships. The Journal of Psychology 134: 169-184.

20. Jordan PJ, Ashkanasy NM, Hartel CE (2002) Emotional intelligence as moderator of emotional and behavioral reactions to job insecurity. Academy of Management Review 27: 361-372.

21. Gardner L, Stough C (2003) Assessing the relationship between workplace emotional intelligence, job satisfaction and organisational commitment. Australian Journal of Psychology 55: 124.

22. Eisenberger R, Armeli S, Rexwinkel B, Lynch PD, Rhoades L (2001) Reciprocation of perceived organizational support. Journal of Applied Psychology 86: 42-51.

23. Chen ZX, Tsui AS, Farh JL (2002) Loyalty to Supervisor vs. Organizationa Commitment: Relationships to Employee Performance in China. Journal of Occupational and Organizational Psychology 75: 339-355.

24. Salovey P, Mayer JD (1990) Emotional intelligence, Imagination, Cognition and Personality 9: 185-211.

25. Mayer JD, Salovey $P$ (1997) What is emotional intelligence? In: Salovey $P$ Sluyter D editors. Emotional development and emotional intelligence, pp: 3-31.

26. Zeidner M, Matthews G, Roberts RD (2004) Emotional intelligence in the workplace: A critical review. Applied Psychology 53: 371-399.

27. Goleman D (1998) Working with emotional intelligence. Bantam.

28. Bar-On R (2006) The Bar-On model of emotional-social intelligence (ESI) Psicothema, p: 18

29. Mayer JD, Caruso D Salovey P (1999) Emotional intelligence meets traditional standards for an intelligence. Intelligence 27: 267-298.

30. Mayer JD, Salovey P, Caruso DR (2004a) A further consideration of the issues of emotional intelligence. Psychological Inquiry 15: 249-255.

31. Sellgren S, Ekvall G, Tomson G. (2007) Nursing staff turnover: does leadership matter? Leadership in Health Services 20: 169-183.

32. Firth L, Mellor DJ, Moore KA, Loquet C (2004) How can managers reduce employee intention to quit?. Journal of Managerial Psychology 19: 170-187.

33. Lee HW, Liu CH (2007) An examination of factors affecting repatriates' turnover intentions. International Journal of Manpower 28: 122-134.

34. Falkenburg K, Schyns B (2007) Work satisfaction, organizational commitment and withdrawal behaviours. Management Research News 30: 708-723.

35. Porter LW, Steers RM, Mowday RT, Boulian PV (1974) Organizational commitment, job satisfaction, and turnover among psychiatric technicians. Journal of Applied Psychology 59: 603.

36. Dulewicz V, Higgs M (1999) Can emotional intelligence be measured and developed? Leadership and Organization Development Journal 20: 242-253.

37. Cooper R, Sawaf A (1997) Executive EQ: Emotional Intelligence in the workplace. Grosset/Putman, London.

38. Nikolaou I, Tsaousis I (2002) Emotional intelligence in the workplace: Exploring its effects on occupational stress and organizational commitment. The International Journal of Organizational Analysis 10: 327-342.

39. Becker TE, Billings RS, Eveleth DM, Gilbert NL (1996) Foci and bases 
Citation: Akhtar MW, Shabir A, Safdar MS, Akhtar MS (2017) Impact of Emotional Intelligence on Turnover Intentions: The Role of Organizational Commitment and Perceive Organizational Support. J Account Mark 6: 259. doi: 10.4172/2168-9601.1000259

Page 7 of 7

of employee commitment: Implications for job performance. Academy Of Management Journal 39: 464-482.

40. Cohen A, Hudecek N (1993) Organizational commitment-turnover relationship across occupational groups: A meta-analysis. Group and Organization Management 18: 188-213.

41. Al-Aameri AS (2000) Job satisfaction and organizational commitment for nurses. Saudi Medical Journal 21: 531-535.

42. Mowday RT, Spencer DG (1981) The influence of task and personality characteristics on employee turnover and absenteeism incidents. Academy of Management Journal 24: 634-642.

43. McNeilly KM, Russ FA (1992) The moderating effect of sales force performance on relationships involving antecedents of turnover. Journal of Personal Selling \& Sales Management 12: 9-20.

44. Yu BB, Egri CP (2005) Human Resource Management Practices and Affective Organizational Commitment: A Comparison of Chinese Employees in a State-Owned Enterprise and a Joint Venture, Asia Pacific journal of Human Resources 43: 332-344.

45. Tsui AS, Pearce JL, Porter LW, Tripoli AM (1997) Alternative Approaches to Employee-Organization Relationships: Does Investment in Employees Pay Off? Academy of Management Journal 40: 1089-1121.

46. Vandenberghe C, Bentein K, Stinghamber F (2004) Affective Commitment to the Organization, Supervisor, and Work Group: Antecedents and Outcomes. Journal of Vocational Behavior 64: 47-71.

47. Eisenberger R, Cummings J, Armeli S, Lynch P (1997) Perceived organizational support, discretionary treatment, and job satisfaction. Journal of Applied Psychology 82: 812-820.

48. Malatesta RM, Tetrick LE (1996) Understanding the dynamics of organizational and supervisory commitment. In Annual Meeting of the Society for Industrial and Organizational Society.

49. Blau PM (1964) The research process in the study of The Dynamics of Bureaucracy. Sociologists at Work, pp: 16-49.

50. Rhoades L, Eisenberger R (2002) Perceived organizational support: a review of the literature.

51. Gouldner HP (1960) Dimensions of organizational commitment. Administrative Science Quarterly, pp: 468-490.
52. Foa EB, Foa UG (1980) Resource theory. In Social exchange, pp: 77-94.

53. Armeli S, Eisenberger R, Fasolo P, Lynch $P$ (1998) Perceived organizational support and police performance: The moderating influence of socioemotional needs. Journal of Applied Psychology 8: 288-297.

54. Akhtar W, Ghufran H, Husnain M, Shahid A (2017) The Effect of Emotiona Intelligence on Employee's Job Performance: The Moderating Role of Perceived Organizational Support. J Account Mark 6: 243.

55. Velicer WF, Fava JL (1998) Effects of variable and subject sampling on factor pattern recovery. Psychological Methods 3: 231-251.

56. Arrindell WA, Ende J (1985) An empirical test of the utility of the observationsto-variables ratio in factor and components analysis. Applied Psychological Measurement 9: 165-178.

57. Mowday RT, Steers RM, Porter LW (1979) The measurement of organizational commitment. Journal of Vocational Behavior 14: 224-247.

58. Bluedorn AC (1982) A unified model of turnover from organizations. Human Relations 35: 135-153.

59. Lucas GH (1985) The relationships between job attitudes, personal characteristics, and job outcomes: A study of retail store managers. Journal of Retailing.

60. Baron RM, Kenny DA (1986) The moderator-mediator variable distinction in social psychological research: Conceptual, strategic, and statistical considerations. Journal of Personality and Social Psychology, pp: 1173.

61. Branham L (2005) The 7 hidden reasons employees leave. American Management, New York, p: 172.

62. Farooq A (2003) Effect of emotional intelligence on academic performance. Unpublished Thesis, Institute of Clinical Psychology, University of Karachi, Pakistan.

63. Poon Teng Fatt J (2002) Emotional intelligence: For human resource managers. Management Research News 25: 57-74.

64. Barth S (2001) 3-D chess: Boosting team productivity through emotional intelligence. Harvard Management Update, p: 1.

65. Dulewicz V, Higgs M (2004) Can emotional intelligence be developed? The International Journal of Human Resource Management 15: 95-111.

66. Slaski M, Cartwright S (2003) Emotional intelligence training and its implications for stress, health and performance. Stress And Health 19: 233-239. 